\title{
EXERCISE TREADMILL TEST IN PATIENTS WITH DIABETES MELLITUS TYPE 2
}

\author{
Aleksandar Antonijevic ${ }^{1}$, Jovana Bradic ${ }^{2}$, Vladimir Zivkovic ${ }^{3}$
}

${ }^{1}$ Medical Center in Uzice/Organizational Unit-Health Center in Pozega, Pozega

${ }^{2}$ University of Kragujevac, Faculty of Medical Sciences, Department of Pharmacy, Kragujevac

${ }^{3}$ University of Kragujevac, Faculty of Medical Sciences, Department of Physiology, Kragujevac

\author{
TEST FIZIČKOG OPTEREĆENJA NA TREDMILU KOD PACIJENATA \\ SA DIJABETES MELITUSOM TIPA 2 \\ Aleksandar Antonijević1 ${ }^{\text {, Jovana Bradić }}{ }^{\text {, Vladimir Živković }}{ }^{3}$ \\ ${ }^{1}$ Zdravstveni centar Užice/Organizaciona jedinica Dom zdravlja Požega, Požega \\ ${ }^{2}$ Univerzitet u Kragujevcu, Fakultet medicinskih nauka, Katedra za farmaciju, Kragujevac \\ ${ }^{3}$ Univerzitet u Kragujevcu, Fakultet medicinskih nauka, Katedra za fiziologiju, Kragujevac
}

Received / Primljen: 14.05.2018.

Accepted / Prihvaćen: 22. 05. 2018.

\begin{abstract}
There is a concern regarding the high incidence of coronary heart disease (CHD) among patients with diabetes mellitus (DM) type 2 since it is a leading cause of mortality in those patients. Exercise treadmill test (ETT) is proposed as a suitable, non-invasive method for identifying asymptomatic patients with ischemic changes, who would benefit from pharmacological treatment, thus contributing to a reduction of adverse cardiovascular events. Therefore the objective of our study was to evaluate myocardial ischemia in asymptomatic patients with DM type 2 by performing ETT. The present investigation was conducted in Health Center Pozega during the year 2018. 40 insulin-dependent, aged $33.05 \pm$ 2.01 years, with DM type 2 were included in the study. They had nor history nor symptoms of cardiac disease. All patients underwent ETT according to Bruce protocol, while 12lead ECG was recorded and blood pressure was monitored. All patients had negative ETT results. Also no ST segment depression, no signs of insufficiency of peripheral circulation, no changes in heart rhythm, no symptoms by the central nervous system were observed. Additionally response of heart rate and blood pressure to exercise was within physiological range. These promising findings indicate that diabetes didn't alter myocardial integrity and function, thus suggesting that coronary reserve in examined patients was preserved.
\end{abstract}

Keywords: Diabetes mellitus type 2, Exercise treadmill test, Coronary heart disease

\section{SAŽETAK}

Postoji zabrinutost zbog visoke stope incidence koronarne bolesti srca (KBS) kod pacijenata sa dijabetes melitusom (DM) tip 2, jer su one vodeći uzrok smrtnosti kod tih pacijenata. Test fizičkog opterećenja na tredmilu (TFOT) predložen je kao pogodna neinvazivna metoda za identifikaciju asimptompatskih pacijenata sa ishemijskim promenama, koji bi imali korist od farmakološkog tretmana, čime bi se doprinelo smanjenu neželjenih kardiovaskularnih dogadjaja. Stoga je cilj naše studije bio da ispita prisustvo ishemije miokarda kod asimptomatskih pacijenata sa DM tip 2 izvodjenjem TFOT. Istraživanje je sprovedeno u Domu zdravlja Požega tokom 2018. godine. U studiju je bilo uključeno 40 insulin zavisnih pacijenata, starosti 33,05 \pm 2,01 ioguнa, sa DM tip 2. Nisu imali istoriju ni simptome bolesti srca. Svi pacijenti su podvrgnuti TFOT po Bruce protokolu, uz snimanje elektrokardiograma (EKG) u 12 odvoda i merenje krvnog pritiska. Svi pacijenti su imali negativan test opterećenja. Takodje uočeno je odsustvo ST depresije, znakova insuficijencije periferne cirkulacije, promena u srčanom ritmu i simptoma od strane centralnog nervnog sistema. Dodatno odgovor srčane frekvence $i$ krvnog pritiska na fizičko opterećenje je bio u fiziološkim granicama. Ovi obećavajući rezultati ukazuju na to da dijabetes nije izmenio integritet i funkciju miokarda, što ukazuje da je koronarna rezerva kod ispitivanih pacijenata očuvana.

Ključne reči: dijabetes melitus tip 2, test fizičkog opterećenja na tredmilu, koronarna bolest srca

\section{sciendo}

UDK: 616.12:616.379-008.64-056.24(497.11)"2018"

Ser J Exp Clin Res 2020; 21 (2): 141-145

DOI: 10.2478/SJECR-2018-0051
Corresponding author: Vladimir Zivkovic, Department of Physiology, Faculty of Medical Sciences, University of Kragujevac
Svetozara Markovica 69, 34000 Kragujevac, Serbia Phone : +381 34 342944, Fax: +381 34 306800/ext 112 E-mail: vladimirziv@gmail.com 


\section{INTRODUCTION}

Diabetes mellitus remains one of the most rapidly growing chronic diseases, with a prevalence increasing at an alarming rate (1). It presents a group of metabolic disorders characterized by inadequate fasting or postprandial hyperglicemia, as a result of lack of insulin secretion or diminished tissue responses to insulin. Consequently metabolism of carbohydrates, fats and proteins is impaired (2). In DM type 2 insulin resistance and/or progressive decrease in the insulin secretion occurs, thus preventing insulin from reaching target tissue $(2,3)$. Condition of chronic hyperglicemia is associated with numerous microvascular and macrovascular complications, leading to a dysfunction of various organs, involving heart and blood vessels, muscle, skin, eyes, kidneys, nerves etc (4). Management of diabetic complications represents a great challenge of the $21^{\text {st }}$ century, both for physicians and scientists, especially when it comes to cardiovascular disorders. There is a great concern regarding the development of coronary heart disease among patients with DM type 2 since it's the main cause of death in those patients. Furthermore numerous data has confirmed that patients with DM type 2 have 2-4 fold higher risk for CHD in comparison to the age-adjusted general population, thus indicating the urgent need for obtaining the correct diagnosis in an asymptomatic stage (5-7).

Regular physical exercise exerts myriad health benefits, involving a regulation of blood pressure, glycemia, lipidemia. Therefore it's been proposed as one of the most efficient non-pharmacological treatment modalities in control of DM type 2. Hypoglycemic effect may be reached by increased need for glucose utilization by skeletal muscle during different training protocols $(8,9)$. Nevertheless, long-term hyperglycemia alters structural and functional properties of the heart, with an emphasis on endothelial dysfunction (10, 11). Exercise tolerance test, as non-invasive test, which involves treadmill and bicycle ergometer exercise, is proposed a great method for assessment of physical capacity of persons with DM type 2 if considering to start with moderate or vigorous fitness program. Additionally diabetic patients are strongly recommended to undergo this test for early detection of ischemic changes in myocardium, taking into consideration the high incidence of CHD (12-14).

Regarding all above mentioned data, the aim of our study was to establish ischemic heart changes in asymptomatic patients with diabetes type 2 by performing exercise treadmill screening test.

\section{SUBJECTS AND METHODS}

\section{Study design}

This study was conducted in the year 2018. The study protocol was approved by the Medical Ethics Committee of The Health Center Požega and was carried out according to the Declaration of Helsinki. All the participants were informed about the research protocol before giving their written consent to participate in the study.

\section{Study population}

In total 40 patients suffering from DM type 2 were included in the study. They were insulin-dependent patients, whose therapy included long- and rapid-acting insulin, in combination with metformine and sulfonylurea derivatives or other oral hypoglycemic drugs. A dose of long-acting insulin or insulin analogue was 14 units daily and rapidacting insulin or its analogue was 24 units daily.

\section{Procedure}

All patients were subjected to physical examination, routine biochemical analysis, electrocardiography and echocardiography. Body weight, height and waist circumference were measured. All patients were instructed to prepare for exercise testing by excluding beta blockers from their therapy on the testing day. It was not necessary to exclude coronary dilators since there were no patients receiving this group of drugs, as well as amiodaron and propafen. Three hours before testing, patients had light meals, smokers (10 patients) didn't smoke and they received a dose of insulin reduced for 4 and regular dose of oral hypoglycemic medications.

Excluding criteria were reflected in the following: presence of aortic stenosis, inflammatory conditions such as pericarditis, myocarditis or endocarditis, blood pressure higher than 135/85 $\mathrm{mmHg}$ during resting and relaxation, rapid uncontrolled atrial fibrillation or other disorders of heart rhythm and cardiac decompensation. Exercise treadmill test (ETT) was conducted according to Bruce protocol. Maximum predicted heart rate was calculated by subtracting the person's age from 220 (210 for women).

12-lead ECG was used for continuously monitoring during the test and blood pressure was measured at rest and every 2 minutes during exercise and recovery period. Furthermore symptoms of all patients were continuously observed. If patient reached $85 \%$ of maximum predicted heart rate it was considered as satisfactory myocardial response. ETT test was considered positive if there is a horizontal (planar) or downsloping ST-segment depression of $>1 \mathrm{~mm}$. The value of BP up to 225 $\mathrm{mm} \mathrm{Hg}$ is interpreted as normal. If patients had experienced fatigue and breathlessness, we would have interrupted test $(16,17)$.

\section{Statistical analysis}

IBM SPSS Statistics 19.0 for Windows was used for statistical analysis. Descriptive statistics was used to calculate average value \pm standard deviation (SD). If there were patients with positive test results, the association between 
their clinical and laboratory characteristics and test results would be assessed using Chi-square test for categorical data. Value of $\mathrm{p}<0.05$ was considered to be statistically significant.

\section{RESULTS}

Clinical characteristics of patients are presented in Table 1, while laboratory characteristics are presented in Table 2. Laboratory values were within reference range. All patients had negative screening test results, with no changes in echocardiography. They were able to complete the ETT, and changes in HR were presented in Figure 1. No ST segment elevations, no signs of insufficiency of peripheral circulation, no symptoms by the central nervous system such as dizziness, presyncopa, ataxy were observed. Furthermore the test was not interrupted due to patient request for any reason. Values of BP were within referent range during whole period of measurement. Additionally there were no changes in heart rhythm during the entire duration of the test.

\section{DISCUSSION}

It's been reported that mild inflammation, increased generation of pro-oxidants, enhanced coagulability, endothelial dysfunction etc play role in occurrence of CDV in patients with DM (17). People with diabetes have six to eight years shorter life expectancy compared to general population and the main reason doesn't lie in diabetes per se, but in developed CHD (18). The complex mechanisms associating CHD and diabetes have been under extensive investigation with the aim to discover novel approach, which would decrease mortality and morbidity rate in these patients. More severe manifestations of $\mathrm{CHD}$ are recorded in patients with diabetes, involving multiple, more peripheral and smaller blood vessels, which is closely related to pronounced difficulties in treatment $(19,20)$. Additionally due to the absence of symptoms, silent ischemia delays time for diagnosis and make the prognosis unfavorable. Therefore application of certain diagnostic procedures which would

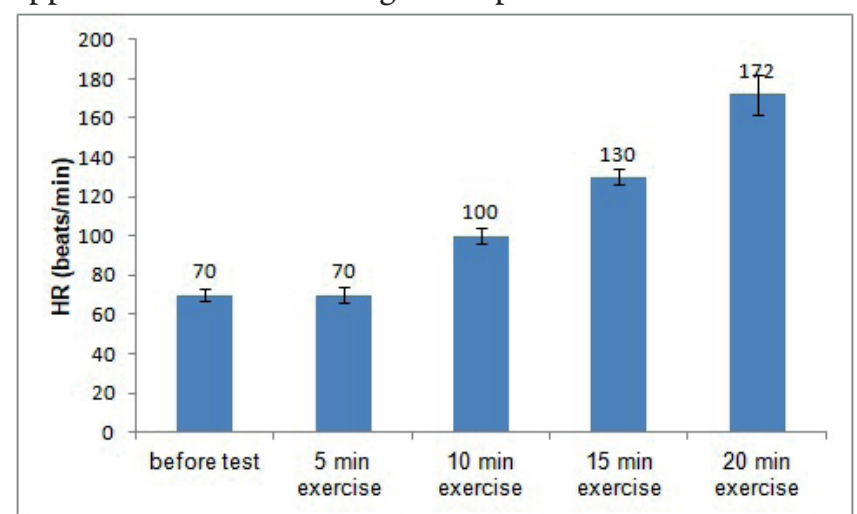

Figure 1. The change of HR during exercise treadmill test. Data are pre sented as mean $\pm S D$
Table 1. Clinical characteristics of patients. Data are expressed as mean \pm SD.

\begin{tabular}{ll} 
Variables & Mean \pm SD \\
\hline Age & $33.05 \pm 2.01$ \\
Sex M/F & $25 / 10$ \\
\hline Weight $(\mathrm{kg})$ & $87.5 \pm 5.21$ \\
\hline Height $(\mathrm{cm})$ & $177.5 \pm 11.02$ \\
Waist circumference $(\mathrm{cm})$ & $90 \pm 4.5$ \\
Duration of disease (years) & $5.5 \pm 1,1$ \\
\hline
\end{tabular}

Table 2. Laboratory analysis and values of blood pressure and heart rate of patients. Data are presented as mean $\pm S D$. rHR- resting heart rate; rSBP-resting systolic blood pressure; rDBP- resting diastolic blood pressure; BG- blood glucose; HbA1c- glycated haemoglobin; TC- Total cholesterol; TG- total triglycerides; $L D L-C$ - low-density lipoproteins cholesterol; $H D L-C$ - high-density lipoproteins cholesterol; AST- aspartate aminotransferase; ALT- alanine aminotransferase; GGT- gamma-glutamyltransferase; TB- total bilirubin; AI- atherogenic index of plasma; CRP$\mathrm{C}$ reactive protein; ESR- erythrocyte sedimentation rate; WBC- white blood cells; RBC-red blood cell; PLT- platelets; HgB- haemoglobine.

\begin{tabular}{|c|c|}
\hline Variables & Mean \pm SD \\
\hline rHR beats/min & $77 \pm 4$ \\
\hline rSBP (mmHg) & $135 \pm 15$ \\
\hline rDBP (mmHg) & $85 \pm 10$ \\
\hline BG $(\mathrm{mmol} / \mathrm{l})$ & $5.8 \pm 0.1$ \\
\hline HbA1c (\%) & $8.12 \pm 1.51$ \\
\hline $\mathrm{TC}(\mathrm{mmol} / \mathrm{l})$ & $5.9 \pm 0.3$ \\
\hline $\mathrm{TG}(\mathrm{mmol} / \mathrm{l})$ & $1.5 \pm 0.1$ \\
\hline LDL-C (mmol/l) & $3 \pm 0.8$ \\
\hline $\mathrm{HDL}-\mathrm{C}(\mathrm{mmol} / \mathrm{l})$ & $1.5 \pm 0.1$ \\
\hline $\operatorname{AST}(\mathrm{U} / \mathrm{l})$ & $30 \pm 2$ \\
\hline $\operatorname{ALT}(\mathrm{U} / \mathrm{l})$ & $25 \pm 2$ \\
\hline GGT (U/l) & $25 \pm 1$ \\
\hline TB (Umol/l) & $10 \pm 0.6$ \\
\hline Urea $(\mathrm{mmol} / \mathrm{l})$ & $5.2 \pm 1.4$ \\
\hline Creatinine $(\mathrm{mmol} / \mathrm{l})$ & $88 \pm 3.1$ \\
\hline $\mathrm{AI}$ & $1 \pm 0.23$ \\
\hline CRP (mg/l) & $1 \pm 0.2$ \\
\hline $\operatorname{ESR}(\mathrm{mm} / \mathrm{hr})$ & $4 \pm 1$ \\
\hline WBC (cells /l) & $8.4 \times 10^{9}$ \\
\hline RBC (cells/l) & $4,4^{\times} 10^{12}$ \\
\hline PLT (cells/l) & $233^{\times} 10^{9}$ \\
\hline HGB $(g / l)$ & $126^{\times} 10^{12}$ \\
\hline $\mathrm{K}(\mathrm{mmol} / \mathrm{l})$ & $4 \pm 0.2$ \\
\hline Urine & Normal \\
\hline
\end{tabular}

detect early ischemic myocardial changes is of a great importance in management of diabetes (21).

We have chosen to apply ETT in our study since it has been proposed as a convenient test for assessing the presence of silent ischemia among patients with diabetes (22). 
Our results have shown that no ST segment depression was found among observed patients and all ECG recordings were within reference range. It's been previously confirmed that not only ST-segment behavior during exercise may predict cardiovascular events, but also exercise time, heart rate and recovery of blood pressure. Moreover abnormal values of heart rate and recovery of blood pressure correlate with a greater risk for adverse cardiovascular outcome (23). Due to the presence of autonomic dysfunction it may be expected that chronotropic response to ETT in diabetic patients is deteriorated, reflected in inability of the heart to increase heart rate when exposed to physical activity (24). A drop in blood pressure after the exercise suggests poor prognosis regarding cardiovascular complications (16). In our study heart rate increased from the baseline 70 beats $/ \mathrm{min}$, up to 172 beats $/ \mathrm{min}$ at the end of 20 minute exercise. We revealed physiological response of the blood pressure to exercise and the absence of progressive decline which would indicate failure of the heart muscle due to possible distinctive coronary disease. Moreover our findings clearly show that the coronary reserve in all examined patients is preserved, indicating that DM 2 doesn't progress in all persons so rapidly and duration time of about 5,5 years in our patients didn't alter myocardial integrity and function. It has been known that symptomatic patients with CHD have a longer disease history in comparison to asymptomatic patients with CHD. The link between the age and presence of CHD has also been reported, thus suggesting that higher positive predictive values of ETT for coronary artery stenosis is among patients older than 55 years (25).

On the one hand, the fact that CHD is frequently missed in the asymptomatic phase of disease emphasizes the need for performing ETT screening test in order to identify individuals who need to receive anti-ischemia therapy (26). Sensitivity of the exercise stress tests is $45-61 \%$, while specificity is in range $70-90 \%$ (27). Beside the frequent use in clinical practice there are several limitations for the test application, such as impossibility of the patients with peripheral neuropathy, peripheral vascular diseases etc to exercise (13). Interestingly data regarding the performance of ETT in asymptomatic patients are controversial. Possibility of false positive responses to ETT in those patients require further confirmation by radionuclide imaging techniques (28). There is a recommendation for application of ETT in elderly patients with more than 10 years history of DM type 2 or shorter if the risk factors such as hypertension, hyperlipidemi, smoking are present (25).

A strong correlation between the presence of hypertension and dyslipidemia and CHD was revealed in patients with diabetes (13). However we weren't able to test the link between associated patients' characteristics and coronary artery stenosis since routine laboratory analysis, general medical examinations as well as ETT result of our selected patients proved to be in reference range. When encountering diabetes as a contemporary disease of mankind bringing so many cardiological complications (numerous forms of heart attacks, stents, by-passes etc), negative ETT results obviously indicate a hope that appropriate insulin and oral hypoglicemic therapy may preserve coronary function. However impact of novel medication, modification of nutrition intake or implementation of physical activity on maintenance of cardiovascular homeostasis shouldn't be missed.

Based on our result we may conclude that patients with DM type 2 achieved predicted heart rate during exercise stress test, without associated ST segment depression, followed by a physiological response of blood pressure. Our promissing results provide insight into the favourable prognosis of these patient in terms of cardiovascular events. Further studies are certainly necessary in order to gain more information about the role of ETT in early diagnosis of $\mathrm{CHD}$ in asymptomatic patients with diabetes, management of recognized patients with $\mathrm{CHD}$ and necessity for different treatment strategies.

\section{REFERENCES}

1. Tabish SA. Is Diabetes Becoming the Biggest Epidemic of the Twenty-first Century? Int J Health Sci (Qassim). 2007; 1(2):V-VIII.

2. Butler AE, Janson J, Bonner-Weir S, Ritzel R, Rizza RA, Butler PC. Beta-cell deficit and increased beta-cell apoptosis in humans with type 2 diabetes. Diabetes. 2003; 52(1):102-10.

3. Ahrén B. Type 2 diabetes, insulin secretion and betacell mass. Curr Mol Med. 2005; 5(3):275-86

4. Cade WT. Diabetes-related microvascular and macrovascular diseases in the physical therapy setting. Phys Ther. 2008; 88(11):1322-35.

5. Laakso M. Cardiovascular disease in type 2 diabetes from population to man to mechanisms: the Kelly West Award Lecture 2008. Diabetes Care. 2010; 33(2):442-9.

6. Dokken B. The Pathophysiology of Cardiovascular Disease and Diabetes: Beyond Blood Pressure and Lipids. Diabetes Spectrum 2008; 21(3): 160-165.

7. Ali MK, Narayan KM, Tandon N. Diabetes \& coronary heart disease: current perspectives. Indian J Med Res. 2010; 132:584-97.

8. Tuomilehto T. Nonpharmacologic Therapy and Exercise in the Prevention of Type 2 Diabetes. Diabetes Care. 2009; 32(Suppl 2): S189-S193.

9. Yanai H, Adachi H, Masui Y, Katsuyama H, Kawaguchi A, Hakoshima M et al. Exercise Therapy for Patients With Type 2 Diabetes: A Narrative Review. J Clin Med Res. 2018;10(5):365-369.

10. Lee JH, Lee R, Hwang MH, Hamilton MT, Park Y. The effects of exercise on vascular endothelial function in type 2 diabetes: a systematic review and meta-analysis. Diabetol Metab Syndr. 2018; 6:10-15.

11. Adeghate E, Singh J. Structural changes in the myocardium during diabetes-induced cardiomyopathy. Heart Fail Rev. 2014; 19(1):15-23. 
12. Kharlip J, Naglieri R, Mitchell BD, Ryan KA, Donner TW. Screening for silent coronary heart disease in type 2 diabetes: clinical application of American Diabetes Association guidelines. Diabetes Care. 2006; 29(3):692-4.

13. Gheydari ME, Jamali M, Hajsheikholeslami F, Yazdani $\mathrm{S}$, Jamali M. Value of exercise tolerance testing in evaluation of diabetic patients presented with atypical chest discomfort. Int J Endocrinol Metab. 2013; 11(1):11-5.

14. Amsterdam EA, Kirk JD, Diercks DB, Turnipseed SD, Lewis WR. Early exercise testing for risk stratification of low-risk patients in chest pain centers. Crit Pathw Cardiol. 2004; 3 (3):114-20.

15. Gibbons RJ, Balady GJ, Beasley JW, Bricker JT, Duvernoy WF, Froelicher VF et al. ACC/AHA Guidelines for Exercise Testing. A report of the American College of Cardiology/American Heart Association Task Force on Practice Guidelines (Committee on Exercise Testing).J Am Coll Cardiol. 1997; 30(1):260-311.

16. Hill J, Timmis A. Exercise tolerance testing. BMJ. 2002; 324.(7345): 1084-1087.

17. Matheus AS, Tannus LR, Cobas RA, Palma CC, Negrato CA, Gomes MB. Impact of diabetes on cardiovascular disease: an update. Int J Hypertens. 2013; 2013:653789

18. Franco OH, Steyerberg EW, Hu FB, Mackenbach J, Nusselder W. Associations of diabetes mellitus with total life expectancy and life expectancy with and without cardiovascular disease. Arch Intern Med. 2007; 167(11):1145-51.

19. Hammoud T, Tanguay JF, Bourassa MG. Management of coronary artery disease: therapeutic options in patients with diabetes. J Am Coll Cardiol. 2000; 36(2):355-65.

20. Melidonis A, Dimopoulos V, Lempidakis E, Hatzissavas J, Kouvaras G, Stefanidis A et al. Angiographic study of coronary artery disease in diabetic patients in com- parison with nondiabetic patients. Angiology. 1999; 50(12):997-1006.

21. Wackers FJ, Young LH, Inzucchi SE, Chyun DA, Davey JA, Barrett EJ et al. Detection of Ischemia in Asymptomatic Diabetics Investigators. Detection of silent myocardial ischemia in asymptomatic diabetic subjects: the DIAD study. Diabetes Care. 2004; 27(8):1954-61.

22. Karanam A, Kumar BG, Koriginja R. Treadmill test to detect silent myocardial ischemia in asymptomatic type 2 diabetes mellitus. J Assoc Physicians India. 2016; 64(1):77.

23. Slavich G, Mapelli P, Fregolent R, Slavich M, Tuniz D. [Non ST ergometric variables in the diabetic patient and their prognostic significance]. Monaldi Arch Chest Dis. 2010; 74(1):28-35

24. Ho PM, Maddox TM, Ross C, Rumsfeld JS, Magid DJ. Impaired chronotropic response to exercise stress testing in patients with diabetes predicts future cardiovascular events. Diabetes Care. 2008; 31(8):1531-3.

25. Joshi AS, Lahane CG, Kashid AA. The result of treadmill test in asymptomatic type 2 diabetes mellitus. Int J Sci Rep. 2017; 3(6):166-172.

26. Rutter MK, Nesto RW. The changing costs and benefits of screening for asymptomatic coronary heart disease in patients with diabetes. Nat Clin Pract Endocrinol Metab. 2007;3(1):26-35

27. Makrilakis K, Liatis S. Cardiovascular Screening for the Asymptomatic Patient with Diabetes: More Cons Than Pros. J Diabetes Res. 2017; 2017:8927473.

28. Acampa W, Cantoni V, Green R, Maio F, Daniele S, Nappi $C$ et al. Prognostic value of normal stress myocardial perfusion imaging in diabetic patients: a metaanalysis. J Nucl Cardiol. 2014; 21(5):893-902. 